\title{
Comparing Intramedullary Nailing, External Fixation and External Fixation followed by Intramedullary Nailing as management for open fractures of the tibial shaft: a Systematic Review

\section{Abstract}

Background: The treatment of open fractures of the tibial shaft is often a dilemma since it requires particular caution and individual assistance for each case.

Methods and Findings: Systematic review of the literature was conducted on the following databases: PubMed and VHL from 2000 to 2013 aiming to compare Intramedullary Nailing (IM Nailing), External Fixation (EF), and EF followed by IM Nailing in the treatment of open fractures of the tibial shaft. After analysis by inclusion criteria 24 articles met the eligibility criteria. The healing time was under 32 weeks, and the nonunion and defective healing rates were under $13.35 \%$ and $16.6 \%$, respectively. The infection rate ranged from $3 \%$ to $53 \%$ for patients treated with $\mathrm{EF}$ as definitive management; from $0 \%$ to $22 \%$ for those treated with IM Nailing as definitive management; and from $0 \%$ to $16.7 \%$ for those who underwent $\mathrm{EF}$ followed by IM Nailing.

Conclusion: The cases treated with EF as definitive management presented shorter healing time as for the analyzed samples. The nonunion cases with greater percentages were those of EF followed by IM Nailing. The studies using IM Nailing as definitive management presented defective healing. Even though few studies analyze hospital stay, it was found to be shorter in the sample treated with EF as definitive management.
Ariovaldo Carvalho Neto', Jucier Gonçalves Júnior ${ }^{1}$, Paula Pessoa Pinheiro', Modesto Leite Rolim Neto1, Marcelo Parente Oliveira ${ }^{1}$

1 Departament Medicine, Federal University of Cariri, Barbalha, Ceará, Brazil.

\section{Contact information:}

Jucier Gonçalves Júnior.

Tel: (055) (88)99176746

Address: 284, Divine Savior Street, Downtown, Barbalha, Ceará, Brazil, 63180000

झ" juciergjunior@hotmail.com 


\section{Introduction}

The open fractures of the tibial shaft usually result from high-energy trauma and have extensive soft tissue damage associated [1]. The National Center for Health Statistics reports an annual incidence of 492,000 fractures of the tibia and fibula per year in the United States [2].

The treatment of open tibial fractures is often a dilemma because it requires particular caution and individual assistance for each case. Although the fixation method for open tibial fractures is controversial, external fixation (EF) is considered the primary emergency procedure. The main advantages of EF are: quick installation; little implant in the injury; less surgical trauma of the damaged soft tissue; easy inspection of the injury; management with little pain; and good stability of the fracture [1].

However, Intramedullary Nailing (IM Nailing) has been increasingly adopted and has showed to be an effective primary definitive fixation method of the open tibial shaft fractures up to the grade IIIA, Gustilo et al. [2, 3]. Besides, some authors present another strategy which is based upon changing the external fixation of open tibial fractures to IM Nailing up to the second week after the initial trauma with lower infection risk [4] and high healing rates [5].

All treatments have their particular disadvantage, immediate unreamed interlocking nailing (immediate nailing) for Gustilo type IIIB open tibial fractures has the risk of deep infection. External fixation is associated with delayed union, nonunion, malunion, and ankle joint stiffness [6]; External fixation followed by delayed interlocking nailing (delayed nailing) is associated with intramedullary and pinsite infection [7].

The treatment of open fractures presented in the literature lies on 3 main management options: EF as definitive treatment, IM Nailing as definitive treatment, and EF followed by IM Nailing. Due to the importance of the open tibial shaft fracture and its correct handling, the present study was ba- sed on the following guiding question: Is there something new we can learn analyzing studies about the different treatments (Intramedullary Nailing, External Fixation, and External Fixation followed by Intramedullary Nailing) of open fractures of the tibial shaft in the period 2000-2013? This review highlights the importance of the open tibial shaft fracture and its correct handling as a fundamental dimension to be considered in patients suffered serious accidents and are received in emergencies. Thus, our objective was to evaluate the current evidence concerning to different aspects (hospital stay, healing time, nonunion, defective healing and infection rates) of three treatments - IM Nailing, EF and EF followed by IM Nailing - and formulating a systematic review with emphasis on the primary fixation methods for this comorbidity. Our hypothesis is that, despite the growing interest toward the theme, EF provides better outcomes than clinical indicators than the other two treatments. Thereby meriting greater theoretical contributions subsidized by clinical multicenter studies as well as research of recognized statistical support as metaanalysis.

\section{Methods}

This systematic qualitative review of the literature was made by collecting manuscripts from the following database: Biblioteca Virtual de Saúde (BVS) and PubMed. The qualitative approach was chosen because, as for the use of quantitative methods such as meta-analysis, the information needed for evenly comparing the sample is not available in all manuscripts - such a fact would limit the analysis to a small number of studies. The period of the literature studied goes from January $1^{\text {st }}, 2000$ to December $1^{\text {st }}, 2013$. The reason to limit the search to the 2000-2013 period is to analyze the main open tibial shaft fixation methods in the last 13 years. The search was conducted using the following descriptors: 
\# 1 "Tibial Fracture" (MeSH);

\# 2 "Open Fracture" (MeSH);

\# 3 "External Fixators" (MeSH);

\# 4 "Intramedullary Nailing" (MeSH);

And their Portuguese correlatives:

\# 5 "Fraturas Expostas" (keywords);

\# 6 "Haste Intramedular" (keywords);

\# 7 "Fixador Externo" (keywords);

\# 8 "Fraturas de tíbia" (keywords);

The data compilation took place during February 2014. The selection of the manuscripts occurred primarily by the analysis of the titles of the abstracts. Then, the articles identified by the search strategy were assessed independently by the authors, according to the following inclusion criteria: (1) original unabridged articles from the CAPES (Coordenação de Aperfeiçoamento de Pessoal de Nível Superior) Journal Gateway, a virtual library linked to Brazil's Ministry of Education having its content restricted to authorized users; (2) articles written in English and/ or Portuguese; (3) articles on open fractures, as well as open and closed fractures, once the results of the open fractures may be individualized. The following were excluded: (1) unoriginal studies such as letters to the editor, reviews, systematic reviews, and editorials; (2) studies whose samples were animals; (3) articles whose case analysis involved pediatric patients. The manuscripts repeated in more than one of the databases were accounted only once.

Subsequently, each selected article was thoroughly read and the data important to this review were collected and organized in a spreadsheet containing: Authors, Year, Type of Treatment, Sample Number (open fractures), Hospital Stay, Healing Time, Nonunion, Defective Healing, and Infection Rates (PICOS) (Table 1). The data were extracted independently by two researchers and the differences analyzed by a senior researcher in the area. Some studies reported tibia shaft fractures in children or animals. These were not compiled/ tabulated because they did not agree with the selected main theme in this research.
The search in the BVS database took 3 steps: a) descriptors \#5 AND \#6 were used, resulting in 17 articles; b) descriptors \#6 AND \#7 were cross-checked, resulting in 8 articles; c) descriptors \#5 AND \#8 were used and 280 manuscripts were found.

The search in the PubMed database also took 3 steps: a) by cross-checking 4 descriptors \#1 AND \#2 AND \#3 AND \#4, 14 articles were found; b) by cross-checking 3 descriptors \#1 AND \#2 AND \#3, 73 articles were found; c) by cross-checking 3 descriptors \#1 AND \#2 AND \#4, 97 articles were found.

This was a literature review therefore no patient recruitment was involved. In this sense, ethical approval was not necessary.

According to the strategy adopted, 489 articles were initially found (Figure 1). After a thorough analysis by the inclusion criteria, 24 articles met the eligibility criteria. Table 1 presents the results obtained in this systematic review from the manuscripts constituting the final sample. The articles were organized according to the fixation strategy. The papers containing more than one management strategy may be analyzed more than once.

Among the analyzed studies, Park et al. [6], Inan et al. [10], and Kaftandziev et al. [11] showed more than one patient sample and a different type of treatment for each sample. When the patients were separated by the type of treatment which they had undergone 27 samples were obtained; they were treated by one the following management options: External Fixation [5, 8-15], Intramedullary Nailing $[2,4,6,10,11,16-23]$, or EF followed by IM Nailing $[1,3,4,6,7]$. The external fixators and IM nails may vary along the studies. The fixators presented were circular and unilateral; the nails were reamed or unreamed.

Hospital stay was mentioned by one study on EF followed by IM Nailing [4] - 22 days; by three studies on IM nailing - 21 days [20], 17.6 days [11], and 10 days [18]; and by two studies on EF - 8.6 days [8], and 21.6 days [11]. 
Table 1. Treatment, Sample Number, Hospital Stay, Nonunion, Defective Healing, and Infection Rates found in the selected articles (PICOS).

\begin{tabular}{|c|c|c|c|c|c|c|c|}
\hline $\begin{array}{l}\text { Author } \\
\text { (Year) }\end{array}$ & Treatment & $\begin{array}{l}\text { Sample Number } \\
\text { (open fractures) }\end{array}$ & $\begin{array}{l}\text { Hospital } \\
\text { Stay }\end{array}$ & $\begin{array}{l}\text { Healing } \\
\text { Time }\end{array}$ & Nonunion & $\begin{array}{c}\text { Defective } \\
\text { Healing }\end{array}$ & $\begin{array}{l}\text { Infection } \\
\text { Rates }\end{array}$ \\
\hline \multicolumn{8}{|c|}{ EF followed by IM Nailing } \\
\hline $\begin{array}{l}\text { Rezende et al. } \\
\text { (2012) [1] }\end{array}$ & $\begin{array}{l}\text { EF followed by } \\
\text { IM Nailing (UR) }\end{array}$ & 38 & - & 19 weeks & $0 \%$ & $7.8 \%$ & $5.20 \%$ \\
\hline $\begin{array}{c}\text { Hungria et al. } \\
\text { (2008) [4] }\end{array}$ & $\begin{array}{l}\text { EF followed } \\
\text { by IM Nailing } \\
\text { (UR L) }\end{array}$ & 36 & 22 days & - & - & - & $0 \%$ \\
\hline $\begin{array}{l}\text { Park et al., } \\
(2007) \text { [6] }\end{array}$ & $\begin{array}{l}\text { EF followed by } \\
\text { IM Nailing (R I) }\end{array}$ & 14 & - & 56 weeks & $36 \%$ & $0 \%$ & $7 \%$ \\
\hline $\begin{array}{l}\text { Yokoyama et } \\
\text { al. (2006) [3] }\end{array}$ & $\begin{array}{l}\text { EF followed by } \\
\text { IM Nailing (L) }\end{array}$ & 42 & - & - & - & - & $\begin{array}{c}16.7 \% \text { deep } \\
\text { infections }\end{array}$ \\
\hline $\begin{array}{l}\text { Ueno et al. } \\
(2006)[7]\end{array}$ & $\begin{array}{c}\text { EF followed by } \\
\text { IM Nailing } \\
(L \text { UR })\end{array}$ & 4 & - & 56 weeks & $25 \%$ & - & $0 \%$ \\
\hline \multicolumn{8}{|c|}{ EF as definitive management } \\
\hline $\begin{array}{l}\text { Wani et al. } \\
\text { (2011)[8] }\end{array}$ & $\mathrm{EF}(\mathrm{I})$ & 60 & 8.6 days & 21.1 weeks & $0 \%$ & $9.9 \%$ & $53.3 \%$ \\
\hline $\begin{array}{c}\text { Dall'Oca et al. } \\
\text { (2010)[9] }\end{array}$ & EF (Uni) & 35 & - & 21 weeks & $5.1 \%$ & $10.2 \%$ & $\begin{array}{l}3 \% \text { deep } \\
\text { infections }\end{array}$ \\
\hline $\begin{array}{l}\text { Keeling et al. } \\
\text { (2008)[5 }\end{array}$ & Ring EF & 38 & - & 31 weeks & $2.22 \%$ & $0 \%$ & $\begin{array}{l}8 \% \text { deep } \\
\text { infections }\end{array}$ \\
\hline $\begin{array}{l}\text { Inan et al. } \\
(2007)[10]\end{array}$ & $\mathrm{EF}(\mathrm{I})$ & 32 & - & 19 weeks & $0 \%$ & $12.5 \%$ & $\begin{array}{c}15.62 \% \\
\text { superficial, } \\
6,25 \% \text { deep }\end{array}$ \\
\hline $\begin{array}{l}\text { Kaftandziev et } \\
\text { al. (2006) [11] }\end{array}$ & EF & 30 & 21.6 days & 38.4 weeks & $13.35 \%$ & $16.6 \%$ & $\begin{array}{c}23.3 \% \\
\text { superficial, } \\
20 \% \text { deep }\end{array}$ \\
\hline \multirow{2}{*}{$\begin{array}{l}\text { Naique et al. } \\
(2006)[12]\end{array}$} & $\mathrm{EF}(\mathrm{I})$ & 36 & - & 29 weeks & $5.5 \%$ & - & - \\
\hline & EF (Uni) & 9 & - & 26 weeks & - & - & - \\
\hline $\begin{array}{l}\text { Kesemenli et } \\
\text { al. (2004)[13] }\end{array}$ & EF (Uni/Circ) & 20 & - & 28 weeks & $5 \%$ & - & $\begin{array}{l}5 \% \text { deep } \\
\text { infections }\end{array}$ \\
\hline $\begin{array}{l}\text { Hosny et al. } \\
\text { (2003)[14] }\end{array}$ & EF Llizarov & 13 & - & 18.8 weeks & $3.8 \%$ & $11.17 \%$ & - \\
\hline $\begin{array}{l}\text { Claes et al. } \\
(2002)[15]\end{array}$ & $\mathrm{EF}$ & 61 & - & 12.7 weeks & - & - & - \\
\hline
\end{tabular}




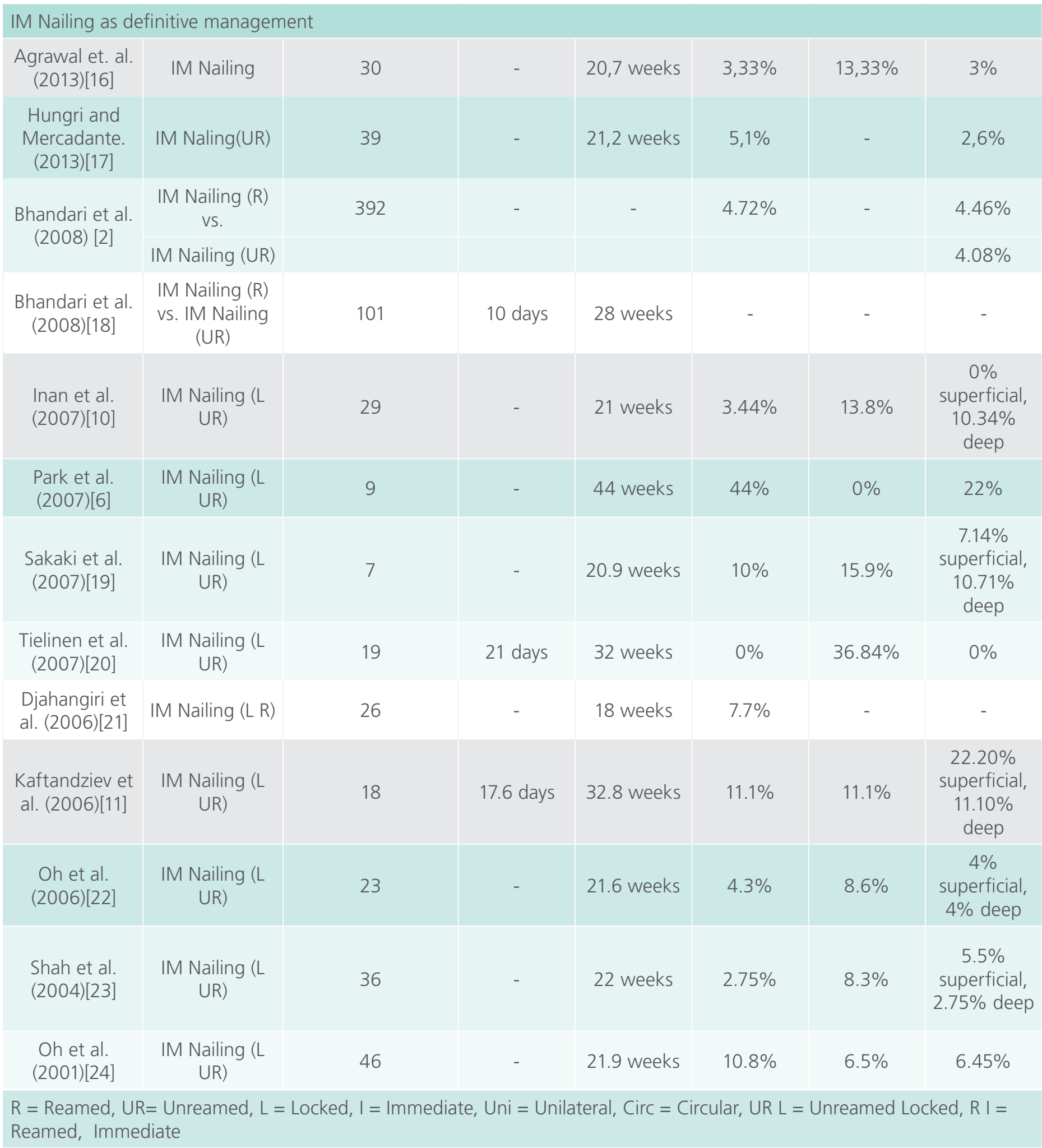


Figure 1: Input/output diagram summarizing the procedures for selecting the studies for the review
Virtual Health Library (BVS)
1) Fraturas de Tíbia (keyword)
2) Haste Intramedular (keyword)
3) Fixador Externo (keyword)
4) Fraturas de Tíbia (keyword)

\section{PubMed}

1) Tibial Fracture (MeSH)

2) Open Fracture $(\mathrm{MeSH})$

3) External Fixators (MeSH)

4) Intramedullary Nailing (MeSH)

$$
\text { \& }
$$

Index: Title

Period: 12.31 .2000 to 03.01 .2013

\section{9 manuscripts}

\section{Inclusion criteria}

1. Unabridged articles available online;

2. Articles written in English and/or Portuguese

3. Articles on open fractures, as well as open and closed fractures, since the results of the open fractures may be individualized

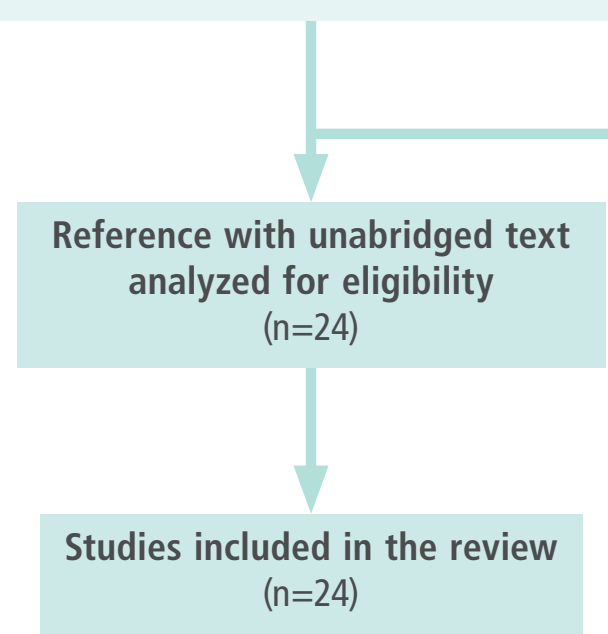


The healing time for EF followed by IM Nailing was mentioned in 3 out of the 5 selected studies: 19 weeks [1], 56 weeks [6], and 56 weeks [7]. Out of the 14 studies on IM Nailing as definitive management, 12 mentioned the healing time [6, 10, 11, 16-24] which ranged from 18 weeks [21] to 44 weeks [6]. All 9 studies on EF as definitive management $[5,8-15]$ presented the average healing time which ranged from 12.9 weeks [15] to 38.4 weeks [11].

Three studies [1, 6, 7] on EF followed by IM Nailing mentioned the nonunion rate which ranged from $0 \%$ [1] to $36 \%$ [6]. Twelve studies on IM Nailing as definitive management showed the nonunion rate $[2,6,10,11,16,17,19-24]$ which ranged from $0 \%$ [20] to 44\% [6]. Eight studies [5, 8-14] on EF as definitive management mentioned the nonunion rate which ranged from $0 \%[8,10]$ to $13.35 \%$ [11].

Two articles $[1,6]$ on EF followed by IM Nailing studied the percentage of defective healing. The rates were $7.8 \%$ and $0 \%$, respectively. Nine articles on IM Nailing as definitive management [6, $10,11,16,19,20,22-24]$ showed the defective healing rates which ranged from $0 \%$ [6] to $36 \%$ [20]. Six articles [5, 8-11, 14] on external fixation as definitive management showed the results for defective healing which ranged from $9.9 \%$ [8] to $16.6 \%$ [11].

All studies on EF followed by IM Nailing [1, 3, 4, $6,7]$ reported the infection rate, which ranged from $0 \%$ [4] to $7 \%$ [6]. As for IM Nailing as definitive management, 11 studies mentioned the infection rate which ranged from $0 \%$ [20] to 33.3\% [10]. Six studies on external fixation as definitive management reported the infection rate which ranged from $53.3 \%[8]$ to $3 \%$ [9].

\section{Discussion}

The lack of studies on three types of management for open tibial shaft fractures is noticed, mainly as for external fixation followed by IM Nailing. The articles occasionally found do not assess the same variables in the results, making the comparison between the techniques difficult. In some cases $[5,6$, $12,19]$, the sample was really small, limiting the analysis of the results.

\section{Hospital Stay}

Five studies $[4,8,11,18,20]$ reported on hospital stay, which ranged from 1 to 3 weeks, considering all types of management for open tibial shaft fracture. The shortest hospital stay was 8.6 days [8] using EF as isolated management; and the longest one was 22 days [4] using EF followed by IM Nailing. It must be emphasized that the minority of the studies reported on hospital stay. Kaftandziev et al. [11], for instance, compares the use of EF and unreamed IM nailing as definitive management in the treatment of open tibial shaft fractures grades IIIA and IIIB, according to Gustilo's classification. The group treated with IM Nailing as definitive management showed shorter average hospital stay when compared to the group treated with EF as definitive management (17.6 versus 21.6 days); however, the authors do not report whether this difference is statistically significant. Moreover, in this study, the authors do not make it clear what criterion was used for choosing either IM Nailing or EF. It is known that, in more severe cases, EF is usually the option. This might explain the longer hospital stay for the group treated with EF.

\section{Conversion Time}

In the studies on EF followed by IM Nailing the conversion time for IM Nailing varied considerably. Hungria et al [4] recommend that conversion time should not exceed 14 days. This time was reasonably longer in two studies: 24 days [6] and 52.4 days [3]. Ueno et al. [9] studied a series of cases in which a shorter conversion time of 2-3 days was tried. In the study of Rezende et al. [1] this time was, in average, 12 days for patients without infection. 
When choosing the treatment for a tibial shaft fracture, several factors must be taken into account, including hospital stay, treatment costs, and the infection risk. With EF followed by IM Nailing, there is an increase in the hospital stay, number of surgeries, use of implants, and other medical equipment and products, such as medicines and dressings. An increase of the infection risk by the IM Nailing is possible when the conversion is delayed, because, when external fixation is kept for a long time, there may be contamination and pin-tract infection and, consequently, medullary canal infection and the IM Nailing tract. The use of IM Nailing followed by EF still needs more studies for safe, efficient procedures to be determined, besides the assessment of its actual cost-benefit relationship.

\section{Healing Time}

In the studies on EF followed by IM Nailing, Ueno et al. [7] and Park et al. [6] showed average 56week healing time. In the studies on EF as definitive management, only Kaftandziev et al. [11] presented average healing over 32 weeks, reaching 38.4 weeks in their sample. The studies on IM Nailing as definitive management reported average 44 weeks [6] and 32.8 weeks [11]. Park et al. [6] did not show any statistically significant difference in the healing time between the group treated by IM Nailing as definitive management and the one treated by $\mathrm{EF}$ followed by IM Nailing.

The general observation of the aforementioned data suggests that the groups treated by EF as definitive management show shorter healing time. However, the heterogeneity between the studies, particularly regarding the characteristics of the patient and more specifically of the fracture to be managed, as well as the applied techniques, do not allow a deeper analysis of the issue.

\section{Nonunion}

One paper [20] on IM Nailing as definitive management mentioned that there were no nonunions. In this work, unreamed nails were applied to 19 tibial shaft fractures and all of them healed. However, 6 fractures took over 8 months to heal, what is considered nonunion in many other studies. Besides, $10 \%$ of the fractures had delayed healing (over 6 months, according the paper), and they had to be dynamized and/or subjected to other procedures (reaming of the shaft, bone graft). In the other studies on IM Nailing as definitive management $[2,6,10,11,16,17,19,20-24]$ the nonunion rate was between $0 \%$ [6] and $11.1 \%$ [11].

In the works on EF as definitive management, two studies $[8,10]$ affirm there were no nonunions. These papers do not mention the time determined as diagnostic criterion for nonunion. Inan et al. [8] reported $12.5 \%$ of delayed healings, but no fracture took more than 32 weeks to heal, whereas Wani et al. [10] affirm that the healing time ranged between 12 and 33 weeks. Three studies on external fixation followed by IM Nailing mentioning nonunion rate were found: $0 \%$ [1], 25\% [7] and 36\% [6]. It is noteworthy that there were differences, even though small ones, as for the criterion used by some authors to diagnose nonunion.

\section{Defective Healing}

Park et al. [6] reported that there was not defective healing in their intramedullary nailing sample, but they do not mention the criteria adopted. The defective healing rate ranged from $6.5 \%$ [24] to $15.9 \%$ [19] in the other studies on IM Nailing, except for Tielinen et al. [20], in which it was 36.8\%. In this paper, 18 Gustilo IIIB and 1 Gustilo IIIC fractures were managed by unreamed IM Nailing and developed complications. Nine of those patients progressed with delayed healing (>24 weeks), needing change of the nail, bone graft, or dynamization of the shaft. Surprisingly, no fracture ended up misaligned. However, 7 fractures shortened $1-2 \mathrm{~cm}$, and 2 of them showed external rotation over $10^{\circ}$. Six studies on EF as definitive management $[5,8-11,14]$ mentioned the defective healing 
rate which ranged from $0 \%$ [5] to $16.6 \%$ [11]. Curiously, Keeling et al. [5] deals with Gustilo III A, B and $C$ fractures caused during war, which would increase the odds of complications, including defective healing. Two studies on EF followed by IM Nailing mentioned defective hailing rate: $7.8 \%$ [1] and $0 \%$ [6]. The discrepancy may be attributed to the sample of the latter [6], as well as to the differences between the methodologies adopted. Rezende et al. [1] discusses more fracture subtypes (I, II, IIIA, according to Gustilo's classification), whereas other paper [6] attains to a more specific subtype: Gustilo IIIB. It is noteworthy that for all management groups, several authors do not offer an account of the criterion used for diagnosing defective healing.

\section{Infection Rate}

The calculation of the infection rate was given by the sum of the numbers of superficial and deep infection. Two papers on external fixation followed by intramedullary nailing reported null infection rate $[3,8]$. Although the infection rate was null in the 2 studies, Hungria et al. [3] analyzed only Gustilo I and II fractures in contrast with the work of Ueno et al. [9], in which the fractures were more severe (Gustilo IIIB), and, hence, more prone to infection. Out of the 10 studies on intramedullary nailing as definitive management, only Tielinen et al. [18] showed $0 \%$. The other studies on intramedullary nailing presented less than $11 \%[4,6,10$, 11, 16, 17, 19, 20-22], except for Sakaki et al. [17], Park et al. [4], and Kaftandziev et al. [11] in which that rate was $17.85 \%, 22.0 \%$, and $33.3 \%$, respectively. Park et al. [4] did not specify the percentages of superficial and deep infection. In the study of Sakaki et al. [17] most infections were deep $(10.71 \%)$, whereas, in the study of Kaftandziev et al. [11] the superficial infections (22.2\%) accounted for increase of the infection rate. A study [2] on external fixation as definitive management stands out for mentioning 53\% infection rate, a number much greater when compared to previous rates. This might be due to the more severe lesions to which this management is applied.

\section{Conclusion}

There are few cases in the literature about open tibial shaft fracture managed by EF followed by IM Nailing. However, a significant sample of patients and articles on IM Nailing and EF as definitive management was found with better results for these groups. Besides, there is no standard procedure for carrying out research into all 3 types of management (EF as definitive management, IM Nailing as definitive management, or EF followed by IM Nailing), which makes the comparison difficult.

In spite of the methodological limitations previously discussed, which make more adequate comparison impossible, it is noticed that the cases management by EF as definitive management have presented shorter healing time for the analyzed samples. The nonunion cases that showed greater percentages were those of EF followed by IM Nailing. The studies on IM Nailing as definitive management found a greater number of defective healings. The shortest hospital stay, although not described by many studies, was indicated by the sample managed with EF as definitive management. There is the need to encourage research comparing the three therapeutic proposals aiming better knowledge of their advantages and disadvantages for optimization of the management of open tibial shaft fracture. 


\section{Acknowledgments}

We are grateful to the Scientific Writing Lab (LABESCI) - Faculty of Medicine, Federal University of Cariri (UFCA).

\section{Conflict of interest}

The authors declare no conflicting of interest.

\section{Role of the funding source}

We have no fundation source.

\section{References}

1. Rezende MP,Silva WRS.Análise dos Resultados de fraturas expostas da diáfise da tíbia tratados com fixação externa e posteriormente conversão com haste intramedular. AHMAutarquia Hospitalar Municipal.Secretaria. 2012; s.n: 20.

2. Bhandari M, Guyatt G, Tornetta P, Schemitsch E, Swiontkowski $M$,Sanders $D$ et al.Study to prospectively evaluate reamed intramedually nails in patients with tibial fractures (S.P.R.I.N.T.): study rationale and design.BMC Musculoskelet Disord. 2008; 9: 91.

3. Yokoyama K, Uchino M,Nakamura K, Ohtsuka H, Suzuki T, Boku T et al. Risk factors for deep infection in secondary intramedullary nailing after external fixation for open tibial fractures.Injury. 2006; 37(6): 554-60.

4. Hungria JOS, Mercadante MT. Osteossíntese provisória das fraturas expostas da diáfise da tíbia com fixador externo não transfixante. Rev. bras. ortop. 2008; 43(1-2): 31-40.

5. Keeling JJ, Gwinn DE, Tintle SM, Andersen RC,McGuigan FX. Short-term outcomes of severe opne wartime tibial fractures treated with ring external fixation.J Bone Joint Surg Am. 2008; 90(12): 2643-51.

6. Park HJ, Uchino $M$, Nakamura $M$, Ueno $M$, Kojima $Y$, Itoman M, Yokoyama K, Suzuki T, Nemoto M. Immediate interlocking nailing versus external fixation followed by delayed interlocking nailing for Gustilo type IIIBopen tibial fractures.J Orthop Surg (Hong Kong). 2007; 15(2): 131-6.

7. Ueno M, Yokoyama K, Nakamura K, Uchino M, Suzuki T, Itoman M. Early unreamed intramedullary nailing without a safety interval ad simultaneous flap coverage following external fixation in type IIIB open tibial fractures: a report of four successful cases.Injury. 2006; 37(3): 289-94.

8. Wani N, Baba A, Kangoo K, Mir M. Role of early llizarov ring fixator in the difinitive management of type II, IIIA and IIIB open tibial shaft fractures. Int Orthop. 2011; 35(6): 915-23.

9. Dall'Oca C, Christodoulidis A, Bortolazzi R, Bortolozzi P, Lavini F. Treatment of 103 displaced tibial diaphyseal fractures with a radiolucent unilateral external fixator. Arch Orthop Trauma Surg. 2010; 130(11): 1377-82.

10. Inan M, Halici M, Ayan I, Tuncel M, Karaoglu S. Treatment of type IIIA open fractures of tibial shaft with Ilizarov external fixator versus undreamed tiba nailing. Arch Orthop Trauma Surg. 2007; 127(8): 617-23.

11. Kaftandziev I, Pejkova S, Saveski J. Operative treatment of III grade open fractures of the tibial diaphysis.Prilozi. 2006; 27(1): 121-31.

12. Naique SB, Pearse M, Nachanhal J. Management of severe open tibial fractures:the need for combined orthopaedic and plastic surgical treatment inspecialist centers. J Bone Joint Surg $\mathrm{Br}$. 2006; 88(3): 351-7. 
13. Kesemenli CC, Kapukaya A,Subaşi M, Arslan H,Necmioğlu S, Kayikçi C. Early prophylactic autogenous bone grafting in type III open tibial fractures. Acta Orthop Belg. 2004; 70(4): 327-31.

14. Hosny G, Fadel M. Ilizarov external fixator for open fractures of the tibial shaft.Int Orthop. 2003; 27(5): 303-6.

15. Claes L, Grass R, Schmickal T, Kisse B,Eggers C, Gerngross H, Mutschler W,Arand M,Wintermeyer T, Wentzensen A(2002) Monitoring and healing analysis of 100 tibial shaft fractures. Langenbecks Arch Surg. 387(3-4): 146-52.

16. Agrawal A, Chauhan VD, Maheshwari RK, Juyal AK(2013) Primary Nailing in the Open Fractures of the Tibia-ls it worth?J Clin Diagn Res. 7(6): 1125-30.

17. Hungri JOS, Mercadante MT. Open tibial shaft fractures (2013) Treatment with intramedullary nailing after provisional stabilization with non penetrating external fixator. Rev. bras. ortop. 48(6): 482-490.

18. Bhandari M, Guyatt G, Tornetta P, Schemitsch EH, Swiontkowki M, Sanders D, Walter SD (2008) Randomized Trial of Reamed and Unreamed Intramedullary Nailing of Tibial Shaft Fractures. J Bone Joint Surg Am. 90(12): 2567-78.

19. Sakaki MA, Crocci AT, Zumiotti AV (2007) Comparative study of the locked Intramedullary nail and ender pins in the treatment of tibial diaphyseal fractures.Clinics. 62(4): 455-64.

20. Tielinen L, Lindahl JE, Turkiainen EJ (2007) Acute undreamed intramedullary nailing and soft tissue recons truction with muscle flaps for the treatment of severe open tibial shaft fractures. Injury. 38(8): 906-12.

21. Djahangiri A, Garofalo R, Chevalley F, Leyvraz PF, Wettstein $M$, Borens O, Schizas C, Mouhsine E. Closed and open grade land II tibial shaft fractures treated by reamed intramedullary nailing. Med Princ Pract. 2006; 15(4): 293-8.

22. Oh CW, Bae SY, Jung DY, Oh JK. Treatment of open tibial shaft fractures using tightly fitted interlocking nailing. Int Orthop. 2006; 30(5): 333-7.

23. Shah RK, Moehring HD, Singh RP, Dhakal A. Surgical Implant Generation Network(SIGN) intramedullary nailing of open fractures of the tibia. Int Orthop. 2004; 28(3): 163-6.

24. Oh CW, Park BC, Ihn JC, Park HJ (2001) Primary unreamed intramedullary nailing for open fractures of the tiba. Int Orthop. 24(6): 338-41

\section{Comment on this article:}

\section{f(B) in $8+s$}

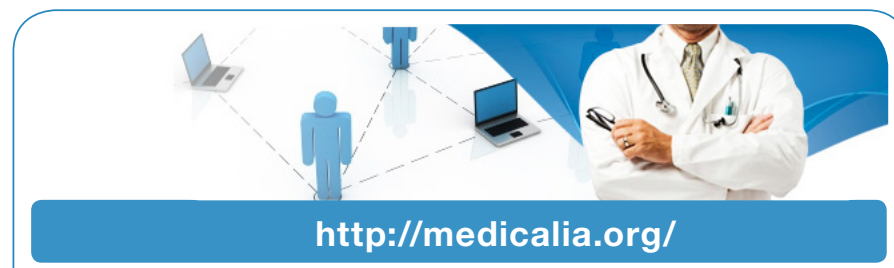

Where Doctors exchange clinical experiences, review their cases and share clinical knowledge. You can also access lots of medical publications for free. Join Now!

\section{Publish with iMedPub}

http://www.imed.pub

International Archives of Medicine is an open access journal publishing articles encompassing all aspects of medical science and clinical practice. IAM is considered a megajournal with independent sections on all areas of medicine. IAM is a really international journal with authors and board members from all around the world. The journal is widely indexed and classified Q1 in category Medicine. 